ISSN 0258-7122

Bangladesh J. Agril. Res. 38(2): 289-299, June 2013

\title{
CHANGES IN SOIL PHYSICAL PROPERTIES AND CROP PRODUCTIVITY AS INFLUENCED BY DIFFERENT TILLAGE DEPTHS AND CROPPING PATTERNS
}

\author{
M. K. ALAM ${ }^{1}$ AND N. SALAHIN ${ }^{2}$
}

\begin{abstract}
A series of field experiments was conducted at BARI central farm to observe the changes in soil densities, moisture retentive properties, and crop productivity as influenced by different tillage depths and cropping patterns. The tillage depth showed significant effect on wheat yield. Grain yield of wheat significantly increased from $2.86 \mathrm{t} / \mathrm{ha}$ (minimum tillage depth) to $5.33 \mathrm{t} / \mathrm{ha}$ (tillage depth up to 20-25 cm). Tillage depths and cropping patterns individually and their interaction significantly affected the yield of BRRI dhan32. The highest grain yield of rice (5.82 t/ha) was found in the tillage depth up to $20-25 \mathrm{~cm}$ under wheat-dhaincha-T. aman cropping pattern, whereas the lowest yield (2.08 t/ha) was found in the minimum tillage depth under wheat-fallow-T. aman cropping pattern. Soil densities and soil moisture retentive properties were significantly affected by interaction of tillage depths and cropping patterns. The bulk density and particle density of soil were decreased but the porosity and soil moisture at field capacity and permanent wilting point were increased with the increase of tillage depths. Tillage depth up to $20-25 \mathrm{~cm}$ by chisel plough under wheatdhaincha-T. aman cropping pattern conserved more moisture in the soil profile and improved other soil physical properties i.e. reduced the bulk density, increased porosity, increased water holding capacity and available water content of soil, thus maintained an optimum soil water infiltration rate and soil strength. The study revealed that the soil physical properties were significantly improved and crop yield significantly increased under tillage depth up to $20-25 \mathrm{~cm}$ by chisel plough under wheat-dhaincha-T. aman cropping pattern.
\end{abstract}

Keywords: Tillage depth, soil physical properties, cropping pattern, wheat yield.

\section{Introduction}

Tillage is an important agronomic practice to make the soil physically, chemically, and biologically suitable to improve seed germination, seedling emergence and for optimal plant growth. Tillage improves soil conditions by altering the mechanical impedance to root penetration, aggregate size distribution, hydraulic conductivity and water holding capacity, which in turn, affects plant growth (Dexter, 1989). Rahman and Islam (1998) and Weiqiang et al. (2004) stated that tillage had significant effect on wheat yield. This might be due to exposure of roots to absorb more moisture and nutrients in deep tillage practices.

\footnotetext{
${ }^{1 \& 2}$ Scientific Officer, Soil Science Division, Bangladesh Agricultural Research Institute (BARI), Gazipur, Bangladesh.
} 
As a result, wheat at grain filling stage does not suffer from water shortage. Cropping pattern has immense effect on soil properties and thereby on crop productivity (Ranamukhaarachchi et al., 2005).

Intensive cropping promotes high levels of nutrient extraction from soils without natural replenishment. Limited practices of legume, green manure, and jute based cropping patterns have led to depletion of soil organic matter content in soils of Bangladesh. Use of green manure, especially legumes in a cropping pattern could help restore crop productivity. Inclusion of cover crops or green manuring crops may be suitable in cropping patterns regarding soil fertility and crop productivity. The major cereal cropping systems of South Asia is rice and wheat grown on the same field but in different seasons during one year. Currently about 12 million hectares of land in Pakistan, Nepal, India, and Bangladesh use this cropping pattern, accounting for nearly one-fourth of the region's cereal production. After rice, wheat has become an important component of cropping pattern in Bangladesh. It is cultivated mostly after cultivation of Aman rice (Mazid et al., 1990). Production of either rice or wheat is low comparing with many other countries because of inappropriate crop, land and nutrient management practices. Crop production could be increased by adopting appropriate tillage operation with different depths and selecting suitable crops in the cropping pattern including green manuring crops, which demands intensive field research. The overall objective of the study was to identify the appropriate tillage depths and cropping pattern for improving soil health and crop productivity and to observe the changes in soil densities, moisture retentive properties, and crop productivity as influenced by different tillage depths and cropping patterns.

\section{Materials and Method \\ Description of experimental site}

A series of experiments were conducted at the Bangladesh Agricultural Research Institute (BARI), Joydebpur, Gazipur during 2008-2009. The study area was under the agro-ecological zone Modhupur Tract and the soil belongs to the Chhiata series of the Grey Terrace Soils (Aeric Albaquept) under the order Inceptisols. The textural class is Clay loam having soil $\mathrm{pH}$ ranging from 5.5-5.7 and the land type is medium high. The climate of the experimental area is subtropical, wet and humid. Heavy rainfall occurs in the monsoon and scanty in the other times.

\section{Treatments and design}

There were nine treatment combinations comprising three tillage depths as: $T_{1}$ minimum tillage depth (0-4 cm), $T_{2^{-}}$tillage depth up to $10-12 \mathrm{~cm}$ and $\mathrm{T}_{3^{-}}$tillage 
depth up to 20-25 cm) and three cropping patterns: $\mathrm{C}_{1}$ - wheat-fallow-T. aman; $\mathrm{C}_{2}$ - wheat-mungbean- $\mathrm{T}$. aman, and $\mathrm{C}_{3}$ - wheat-dhaincha-T. aman were examined in a split-plot design with three replications.

\section{Land preparation, seed sowing/ transplanting, fertilizer application and intercultural operation}

In minimum tillage depth $(0-4 \mathrm{~cm})$ seeds were placed just by making furrow with a hand rake. The tillage depth up to 10-12 $\mathrm{cm}$ was maintained by a power tiller, whereas the tillage depth up to $20-25 \mathrm{~cm}$ was maintained by a chisel plough. The seeds of the first crop, wheat of all patterns were sown on 27 November 2008. The seeds of mungbean and dhaincha were sown in the fourth week of March 2009. Forty-day old seedlings of T. aman rice (BRRIdhan32) were transplanted in the second week of July 2009 at $25 \mathrm{~cm}$ apart from rows maintaining $15 \mathrm{~cm}$ hill to hill distance and 3 seedlings per hill. Necessary gap filling was done at 8 days after transplanting. The crops, wheat and $\mathrm{T}$. aman were irrigated as and when necessary whereas mungbean and dhaincha were grown under rainfed condition for targeting a high yield goal of the crops in the cropping patterns the rates of chemical fertilizer for each component crop were calculated based on soil test results using the FRG 2005 (BARC, 2005). Weeding and other intercultural operations were done as and when necessary.

\section{Crop harvesting and data collection}

Wheat was harvested in first week of May in both years. Mungbean was harvested from first to third week of June 2009. After picking the pod, the remaining biomass of mungbean was incorporated in the soil. The total biomass of dhaincha was incorporated in the soil in the fourth week of June. Rice crop was harvested in the second week of November 2009 at full maturity. For data collection of wheat and rice, ten hills from each plot were sampled randomly. Both the crop (wheat and rice) was cut at the ground level. Threshing, cleaning, and drying of grain were done separately plot-wise. The weights of grain and straw were recorded plot-wise.

\section{Determination of different soil properties}

Soil samples were collected from the experimental field at the three different sampling depths $(0-15 \mathrm{~cm})$ after the completion of experiment i.e., after the harvest of T. aman rice and analyzed in the laboratory for $\mathrm{pH}, \mathrm{OM}, \mathrm{N}, \mathrm{P}, \mathrm{K}$, and Zn following standard procedures (Page et al., 1982). Particle size distribution and textural class analysis of the collected soils was done by hydrometer method (Black, 1965). Bulk density and particle density of the soil samples were determined by core sampler method and Pycnometer method, respectively (Karim et al., 1988). The soil porosity was computed from the relationship 
between bulk density and particle density using the equation 1 . Soil moisture at field capacity and permanent wilting point were measured using pressure plate apparatus, where available water was calculated using the equation 2 (Black, 1965).

Porosity $(\%)=(1-\mathrm{BD} / \mathrm{PD}) \times 100$

$\mathrm{d}=($ FC-PWP $) / 100 \times \mathrm{BD} \times$ soil depth

The collected data viz., soil bulk density (BD), particle density (PD), porosity, field capacity, permanent wilting point, available water (d) and yields were statistically analyzed by F-test to examine the treatment effects and the mean differences were adjudged by Least Significant Difference Test (Gomez and Gomez, 1984) and ranking was indicated by letters. Correlation and regression between grain yields with yield components was performed. The software package MSTAT was followed for statistical analysis.

Table 1. Initial soil densities and soil moisture retentive properties of experimental plot (Inceptisols).

\begin{tabular}{c|c}
\hline Particle size distribution & Value \\
\hline Sand (\%) & 35.30 \\
Silt (\%) & 37.29 \\
Clay (\%) & 27.41 \\
Textural class & Clay loam \\
Bulk Density $\left(\mathrm{g} \mathrm{cm}^{-3}\right)$ & 1.52 \\
Particle Density $\left(\mathrm{g} \mathrm{cm}^{-3}\right)$ & 2.58 \\
Porosity (\%) & 37.98 \\
Field Capacity (\%) & 28.00 \\
Permanent wilting point (\%) & 13.50 \\
Available water content $(0-15 \mathrm{~cm})$ & 3.05 \\
\hline
\end{tabular}

\section{Results and Discussion}

\section{Effect of tillage depths and cropping patterns on soil densities and porosity}

The effect of tillage depths alone on soil densities was insignificant. But the effects of cropping patterns alone and the interaction effect of tillage depths and cropping patterns on soil bulk density was significant (Table 2). The lowest bulk density $\left(1.45 \mathrm{~g} \mathrm{~cm}^{-3}\right)$ was recorded in tillage depth up to $20-25 \mathrm{~cm}$ under wheatdhaincha-T. aman cropping pattern, whereas it was $1.49 \mathrm{~cm}^{-3}$ in minimum tillage depth under wheat-fallow-T. aman cropping pattern. The higher amount of added biomass from dhaincha and coupled with deep ploughing made soil loose, porous and less squeezed and therefore, the lower bulk density was found under tillage 
depth up to 20-25 cm under wheat-dhaincha-T. aman cropping pattern. These findings are in agreement with the studies of Husnjak et al. (2002) and Rahman et al. (2007). The effects of tillage depths and cropping patterns on soil particle density were insignificant but their interactions showed significant result (Table 2). The soil particle density ranged from 2.55 to $2.58 \mathrm{~g} \mathrm{~cm}^{-3}$ in the surface layer $(0-15 \mathrm{~cm})$. It is fact that the soil particle density is not altered easily by normal physical manipulation of soil. Its value decreases with the increase of organic matter content of the soil.

Table 2. Bulk density, particle density and porosity at $0-15 \mathrm{~cm}$ soil depth of post experimental soil as influenced by tillage depths and cropping patterns.

\begin{tabular}{c|c|c|c}
\hline \multirow{2}{*}{ Treatments } & \multicolumn{3}{|c}{ Soil parameters } \\
\cline { 2 - 4 } & $\begin{array}{c}\text { Bulk density } \\
\left(\mathrm{g} \mathrm{cm}^{-3}\right)\end{array}$ & $\begin{array}{c}\text { Particle density } \\
\left(\mathrm{g} \mathrm{cm}^{-3}\right)\end{array}$ & Porosity (\%) \\
\hline Tillage depths & & & \\
$\mathrm{T}_{1}$ & 1.49 & 2.58 & 42.25 \\
$\mathrm{~T}_{2}$ & 1.48 & 2.57 & 42.41 \\
$\mathrm{~T}_{3}$ & 1.46 & 2.55 & 42.75 \\
$C V(\%)$ & 2.95 & 2.43 & 3.61 \\
$S E( \pm)$ & 0.008 & 0.004 & 0.403 \\
Cropping patterns & & & \\
$\mathrm{C}_{1}$ & $1.48 \mathrm{a}$ & 2.57 & 42.41 \\
$\mathrm{C}_{2}$ & $1.47 \mathrm{~b}$ & 2.57 & 42.80 \\
$\mathrm{C}_{3}$ & $1.47 \mathrm{~b}$ & 2.57 & 42.80 \\
$C V(\%)$ & 2.95 & 2.43 & 3.61 \\
$S E( \pm)$ & 0.005 & 0.003 & 0.228 \\
Interaction of tillage depth and cropping patterns & & \\
$\mathrm{T}_{1} \mathrm{C}_{1}$ & $1.48 \mathrm{a}$ & $2.57 \mathrm{ab}$ & $42.41 \mathrm{~b}$ \\
$\mathrm{~T}_{1} \mathrm{C}_{2}$ & $1.49 \mathrm{a}$ & $2.58 \mathrm{a}$ & $42.25 \mathrm{ab}$ \\
$\mathrm{T}_{1} \mathrm{C}_{3}$ & $1.49 \mathrm{a}$ & $2.58 \mathrm{a}$ & $42.25 \mathrm{ab}$ \\
$\mathrm{T}_{2} \mathrm{C}_{1}$ & $1.49 \mathrm{a}$ & $2.58 \mathrm{a}$ & $42.25 \mathrm{ab}$ \\
$\mathrm{T}_{2} \mathrm{C}_{2}$ & $1.48 \mathrm{ab}$ & $2.57 \mathrm{ab}$ & $42.42 \mathrm{ab}$ \\
$\mathrm{T}_{2} \mathrm{C}_{3}$ & $1.47 \mathrm{bc}$ & $2.57 \mathrm{ab}$ & $42.80 \mathrm{ab}$ \\
$\mathrm{T}_{3} \mathrm{C}_{1}$ & $1.47 \mathrm{bd}$ & $2.56 \mathrm{bc}$ & $42.58 \mathrm{ab}$ \\
$\mathrm{T}_{3} \mathrm{C}_{2}$ & $1.46 \mathrm{~cd}$ & $2.55 \mathrm{c}$ & $42.75 \mathrm{ab}$ \\
$\mathrm{T}_{3} \mathrm{C}_{3}$ & $1.45 \mathrm{~d}$ & $2.55 \mathrm{bc}$ & $43.14 \mathrm{a}$ \\
$C V(\%)$ & 2.95 & 2.43 & 3.61 \\
$S E( \pm)$ & 0.008 & 0.005 & 0.395 \\
\hline
\end{tabular}

Legend:

$\mathrm{T}_{1}$ - minimum tillage depth $(0-4 \mathrm{~cm})$

$\mathrm{C}_{1}$ - wheat-fallow-T. aman

$\mathrm{T}_{2}$ - tillage depth up to $10-12 \mathrm{~cm}$

$\mathrm{C}_{2}$ - wheat-mungbean- $\mathrm{T}$. aman

$\mathrm{T}_{3}$ - tillage depth up to $20-25 \mathrm{~cm}$

$\mathrm{C}_{3}$ - wheat-dhaincha-T. aman 
The effects of different tillage depths and cropping patterns separately on soil porosity were found insignificant (Table 2). However, their interaction effect on soil porosity was found significant. The soil porosity ranged from 42.25 to $42.80 \%$. The lowest soil porosity $42.25 \%$ was recorded in minimum tillage depth $(0-4 \mathrm{~cm})$ under wheat-fallow-T. aman cropping pattern whereas highest porosity was observed in tillage depth up to $20-25 \mathrm{~cm}$ under wheat-dhaincha-T. aman cropping pattern, where incorporation of green manure made the soil more aggregated and porous. As the porosity is calculated from the relation between bulk density and particle density of soil, it is very much influenced by the soil bulk density as particle density is not greatly altered by the agricultural manipulation.

\section{Effects of tillage depths and cropping patterns on soil moisture retentive properties}

The effect of different tillage practices on soil field capacity (FC) was found significant, but cropping patterns did not show any significant effect on it. However, the interaction effect of tillage depths and cropping patterns on FC was found significant (Table 3). The soil moisture at field capacity varied from 24.11 to $31.33 \%$. The lowest FC of $24.11 \%$ was recorded in the minimum tillage under wheat-fallow-T. aman cropping pattern and the highest was $31.33 \%$ in the tillage depth up to 20-25 cm under wheat-dhaincha-T. aman cropping pattern.

The bulk density of initial soil was $1.52 \mathrm{~g} \mathrm{~cm}^{-3}$, which decreased to $1.45 \mathrm{~g} \mathrm{~cm}^{-3}$ in the surface layer under wheat-dhaincha-T. aman cropping pattern, which indicated that addition of sufficient amount of biomass in conjunction with tillage made surface soil loose and porous, thus enhanced the capacity of soil to store and retain more moisture. Therefore, the field capacity of surface soil was increased.

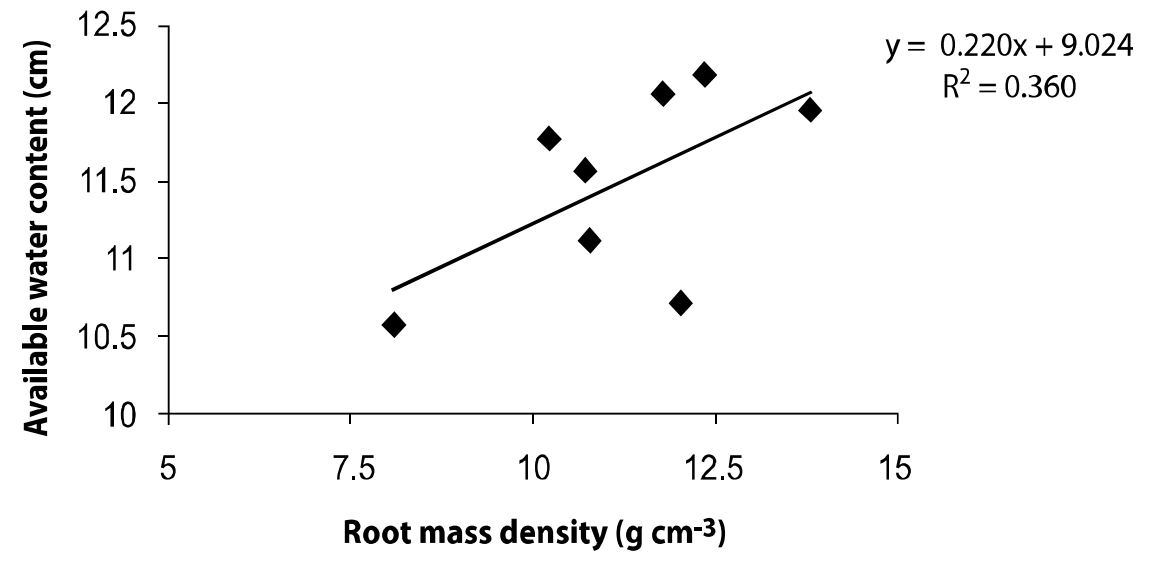

Fig. 4. Correlation between available water content and root mass density. 
Table 3. Moisture retentive properties of post experiment soil as influenced by different tillage depths and cropping patterns.

\begin{tabular}{|c|c|c|c|}
\hline \multirow[b]{2}{*}{ Treatments } & \multicolumn{3}{|c|}{ Soil parameters } \\
\hline & Field capacity (\%) & $\begin{array}{c}\text { Permanent wilting } \\
\text { point }(\%)\end{array}$ & $\begin{array}{l}\text { Available water } \\
(\mathrm{cm}) \text { up to } 15 \mathrm{~cm} \\
\text { soil depth }\end{array}$ \\
\hline \multicolumn{4}{|l|}{ Tillage depths } \\
\hline $\mathrm{T}_{1}$ & $24.45 b$ & $10.69 \mathrm{~b}$ & 3.08 \\
\hline $\mathrm{T}_{2}$ & $27.53 a b$ & $12.64 \mathrm{ab}$ & 3.31 \\
\hline $\mathrm{T}_{3}$ & $30.93 a$ & $15.05 a$ & 3.48 \\
\hline$C V(\%)$ & 8.09 & 6.32 & 7.39 \\
\hline$S E( \pm)$ & 1.146 & 0.943 & 0.14 \\
\hline \multicolumn{4}{|l|}{ Cropping patterns } \\
\hline $\mathrm{C}_{1}$ & 27.22 & $12.42 \mathrm{c}$ & 3.30 \\
\hline $\mathrm{C}_{2}$ & 27.63 & $12.76 \mathrm{~b}$ & 3.28 \\
\hline $\mathrm{C}_{3}$ & 28.06 & 13.19a & 3.28 \\
\hline$C V(\%)$ & 8.09 & 6.32 & 7.39 \\
\hline$S E( \pm)$ & 0.746 & 0.269 & 0.191 \\
\hline \multicolumn{4}{|c|}{ Interaction of tillage depths and cropping patterns } \\
\hline $\mathrm{T}_{1} \mathrm{C}_{1}$ & 24.11d & $10.48 \mathrm{~g}$ & 3.05e \\
\hline $\mathrm{T}_{1} \mathrm{C}_{2}$ & $24.50 \mathrm{~cd}$ & $10.59 \mathrm{fg}$ & $3.11 d$ \\
\hline $\mathrm{T}_{1} \mathrm{C}_{3}$ & $24.75 \mathrm{~cd}$ & $11.00 \mathrm{f}$ & 3.07e \\
\hline $\mathrm{T}_{2} \mathrm{C}_{1}$ & 27.23bd & $12.23 \mathrm{e}$ & $3.36 \mathrm{c}$ \\
\hline $\mathrm{T}_{2} \mathrm{C}_{2}$ & $27.25 \mathrm{bd}$ & $12.70 \mathrm{~d}$ & $3.23 \mathrm{~cd}$ \\
\hline $\mathrm{T}_{2} \mathrm{C}_{3}$ & 28.11ac & $12.98 \mathrm{~d}$ & $3.34 \mathrm{c}$ \\
\hline $\mathrm{T}_{3} \mathrm{C}_{1}$ & $30.32 \mathrm{ab}$ & $14.55 \mathrm{c}$ & 3.48a \\
\hline $\mathrm{T}_{3} \mathrm{C}_{2}$ & $31.15 \mathrm{ab}$ & $15.00 \mathrm{~b}$ & 3.45ab \\
\hline $\mathrm{T}_{3} \mathrm{C}_{3}$ & 31.33a & $15.58 \mathrm{a}$ & $3.52 \mathrm{a}$ \\
\hline$C V(\%)$ & 8.09 & 6.32 & 7.39 \\
\hline$S E( \pm)$ & 1.29 & 0.47 & 0.33 \\
\hline
\end{tabular}

\section{Legend:}

$\mathrm{T}_{1}$ - minimum tillage depth $(0-4 \mathrm{~cm})$

$\mathrm{C}_{1}$ - wheat-fallow-T. aman

$\mathrm{T}_{2}$ - tillage depth up to $10-12 \mathrm{~cm}$

$\mathrm{C}_{2}$ - wheat-mungbean-T. aman

$\mathrm{T}_{3}$ - tillage depth up to $20-25 \mathrm{~cm}$ )

$\mathrm{C}_{3}$ - wheat-dhaincha-T. aman

The permanent wilting point (PWP) varied significantly due to different tillage depths, cropping patterns, and their interaction (Table 3). The lowest PWP $(10.48 \%)$ found in the minimum tillage depth $(0-4 \mathrm{~cm})$ under wheat-fallow-T. aman and maximum value of $15.58 \%$ was recorded from tillage depth up to $20-25$ $\mathrm{cm}$ under wheat-dhaincha-T. aman cropping pattern. Similarly available water content of soil under wheat-dhaincha-T. aman cropping pattern was higher than that of wheat-fallow-T. aman cropping pattern because of more organic matter 
addition in soils through green manuring using dhaincha. This attributed to the higher PWP of soils under wheat-dhaincha-T. aman cropping pattern. The effect of tillage depths and cropping patterns interaction was found significant on available soil water content (Table 3). However, available soil moisture was found in increasing trends from minimum to $20-25 \mathrm{~cm}$ tillage depth. This indicated that tillage depth up to 20-25 cm particularly in the rabi season may help increase the available water contents. By manipulating soil moisture dynamics with tillage could be one of the more feasible ways of increasing yields of crops (Rahman and Islam, 1998). The available water content was found positively correlated with the root mass density (Fig. 4).

\section{Effect of tillage depths and cropping patterns on root mass density}

The interaction effect of tillage depths and cropping patterns on root mass density was found significant in all three sampling depths. The highest root mass density (9.15 $\mathrm{mg} \mathrm{cm}^{-3}$ ) was observed in tillage up to 10-12 $\mathrm{cm}$ depth maintained by chisel plough under wheat-dhaincha-T. aman cropping pattern, whereas the lowest root density (5.96 $\mathrm{mg} \mathrm{cm}^{-3}$ ) was found in zero tillageunder wheat-fallow-T. aman cropping pattern at $0-15 \mathrm{~cm}$ soil depth (Table 4). The root mass density ranged from 9.15 to $5.96 \mathrm{mg} \mathrm{cm}^{-3}$ and 1.12 to $2.84 \mathrm{mg} \mathrm{cm}^{-3}$ in the surface and the subsoil layer, respectively. At 30-50 cm depth, root mass density ranged from 0.70 and $1.82 \mathrm{mg} \mathrm{cm}^{-3}$. The lowest root mass density $0.70 \mathrm{mg} \mathrm{cm}^{-3}$ was recorded in zero tillage under wheat-dhaincha-T. aman cropping pattern in the deep soil layer (30$50 \mathrm{~cm}$ depth). With the increase in soil depth the root mass density decreased (Table 4). It may be due to the incorporation of biomass from sesbania, which favored higher growth of plant roots (Kulakova et al., 1996). The result of this study are in agreement with the observation found by Hassan et al. (2005), Matin (1996), Khan et al., (1997) and Vars et al. (1998).

Table 4. Interaction effect of tillage depths and cropping patterns on root mass density $\left(\mathrm{mg} \mathrm{cm}^{-3}\right)$.

\begin{tabular}{c|c|c|c}
\hline \multirow{2}{*}{ Treatments } & \multicolumn{3}{|c}{ Root mass density } \\
\cline { 2 - 4 } & $0-15$ & $15-30$ & $30-50$ \\
\hline $\mathrm{T}_{1} \mathrm{C}_{1}$ & $5.96 \mathrm{~d}$ & $1.12 \mathrm{~d}$ & $0.90 \mathrm{de}$ \\
$\mathrm{T}_{1} \mathrm{C}_{2}$ & $9.93 \mathrm{~d}$ & $1.29 \mathrm{~d}$ & $0.80 \mathrm{ef}$ \\
$\mathrm{T}_{1} \mathrm{C}_{3}$ & $6.07 \mathrm{~d}$ & $1.33 \mathrm{~d}$ & $0.70 \mathrm{f}$ \\
$\mathrm{T}_{2} \mathrm{C}_{1}$ & $7.05 \mathrm{c}$ & $2.23 \mathrm{c}$ & $0.93 \mathrm{~d}$ \\
$\mathrm{~T}_{2} \mathrm{C}_{2}$ & $7.22 \mathrm{c}$ & $2.55 \mathrm{~b}$ & $1.00 \mathrm{~d}$ \\
$\mathrm{~T}_{2} \mathrm{C}_{3}$ & $7.09 \mathrm{c}$ & $2.49 \mathrm{bc}$ & $1.13 \mathrm{c}$ \\
$\mathrm{T}_{3} \mathrm{C}_{1}$ & $7.92 \mathrm{~b}$ & $2.44 \mathrm{bc}$ & $1.42 \mathrm{~b}$ \\
$\mathrm{~T}_{3} \mathrm{C}_{2}$ & $8.23 \mathrm{~b}$ & $2.67 \mathrm{ab}$ & $1.46 \mathrm{~b}$ \\
$\mathrm{~T}_{3} \mathrm{C}_{3}$ & $9.15 \mathrm{a}$ & $2.84 \mathrm{a}$ & $1.82 \mathrm{a}$ \\
\hline$C V(\%)$ & 3.61 & 6.55 & 5.86 \\
$S E( \pm)$ & 0.11 & 0.09 & 0.04 \\
\hline
\end{tabular}




\section{Impact of tillage depths and cropping patterns on yield of wheat and rice}

The effects of tillage depths on grain yield of wheat and rice were found significant and varied among three tillage depths (Fig. 1 and 2). The highest yields of both the crops were found under the tillage depth up to $20-25 \mathrm{~cm}$ and the lowest yields were obtained in the minimum tillage depth. The deep tillage (20-25 cm) might have favoured the roots to proliferate down into the deeper layers of the soil profile to extract more nutrients and moisture that has led to higher growth and yield of both the crops. Higher tillage depth favorably influenced the soil-water-plant ecosystem, thereby improved crop yields and quality (Ardell et al., 2000; Ranjan et al., 2006; Jabro et al., 2010) which is in agreement with the present findings.

Different cropping patterns showed a significant impact on grain yields of rice. The highest grain yield of rice (4.14 t/ha) was recorded in wheat-dhaincha$\mathrm{T}$. aman cropping pattern, which was statistically similar to the yield of rice found under wheat-mungbean-T. aman cropping pattern (Fig. 3). This might be because of incorporation of biomass in soils using mungbean and sesbania (Table 4). The incorporation of biomass released nutrients to soils, improved physical environment of soil and enhanced crop uptake and thereby increased crop yields (Reddy et al., 2004). Interaction effects of tillage depths and cropping patterns on crop yield were also found significant.

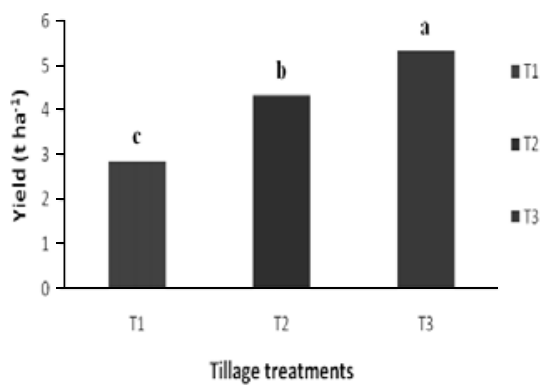

Fig.1. Effect of different tillage depths on grain yield of wheat.

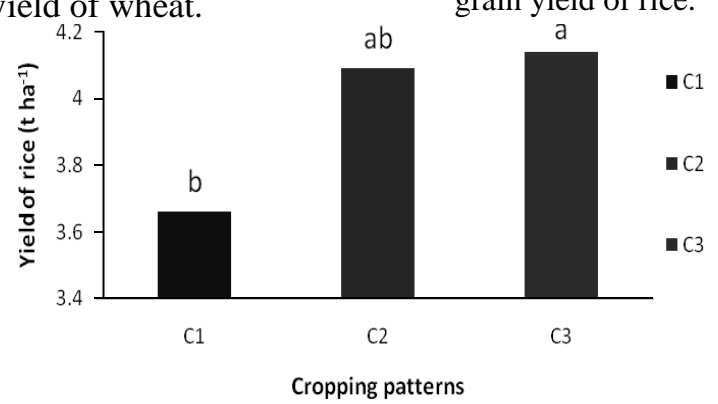

Fig. 3. Effect of different cropping patterns on grain yield of rice.

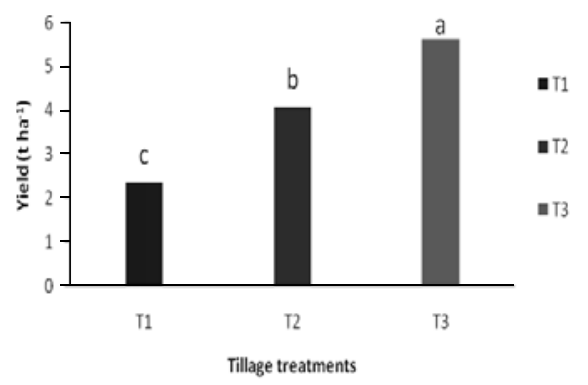

Fig. 2. Effect of different tillage depths on grain yield of rice.

2




\section{Interaction effect of tillage depths and cropping pattern on the crop yields}

The yield under interaction of both the variables was found insignificant.

Table 4. Biomass yields of mungbean and dhaincha under different tillage depths.

\begin{tabular}{c|cc}
\hline \multirow{2}{*}{$\begin{array}{c}\text { Tillage } \\
\text { treatments }\end{array}$} & \multicolumn{2}{|c}{ Biomass yield (t/ha) } \\
\cline { 2 - 3 } & Mungbean & Dhaincha \\
\hline $\mathrm{T}_{1}$ & $9.21 \mathrm{c}$ & $16.34 \mathrm{~b}$ \\
$\mathrm{~T}_{2}$ & $10.86 \mathrm{~b}$ & $17.92 \mathrm{a}$ \\
$\mathrm{T}_{3}$ & $13.87 \mathrm{a}$ & $18.99 \mathrm{a}$ \\
\hline $\mathrm{CV}(\%)$ & 5.10 & 4.02 \\
$\mathrm{SE}( \pm)$ & 0.33 & 0.41 \\
\hline
\end{tabular}

\section{Conclusion}

Deep tillage $(20-25 \mathrm{~cm})$ by chisel plough under wheat-dhaincha-T. aman cropping pattern have improved the soil physical environment, made the soil softer indicated by reduced bulk density, increased the moisture retentive capacity of soil and ultimately favoured in increased yield of both wheat and rice crops. The lowest yield of both the crops was found in minimum tillage under wheat-fallow-T. aman cropping pattern.

\section{References}

Ardell, D., A. L. Halvorson, J. N. Black, S. D. Krupingley, B. J. Merril, G. Wienhold and K. I. Tonaka. 2001. Spring wheat response to tillage system and nitrogen fertilization within crop fallow system. Agron. J. 92: 151.

BARC (Bangladesh Agricultural Research Council). 2005. Fertilizer Recommendation Guide. Soils pub no, 41, Bangladesh Agril. Res. Council, Farmgate, Dhaka.

Black, C. A. 1965. Method of soil analysis (Part -I and II). Amer. Soc. Agron. Inc. Madison, Wiscosin, USA. P. 770.

Dexter, A. R. 1989. Soil mechanics relation to tillage implements and root penetration in lowland soils. Soil Physics and Rice. Int. Rice Res. Inst. Los Banos, Philippines, Pp. 261-281.

Gomez, K. A. and A. A. Gomez. 1984. Statistical Procedures for Agricultural Research 2nd Edn. IRRI, Los Banos, Languna, The Philippines, Pp. 62-74.

Husunjak, S., D. Filipovic and S. Kosutic. 2002. Influence of different tillage systems on soil properties and crop yield. Rostlinná Výroba 48 (6): 249-254.

Jabro, J. D., W. B. Stevens, W. M. Iversen and R. G. Evans. 2010. Tillage depth effects on soil physical properties, sugarbeet yield, and sugarbeet quality. Com. Soil Sci. Plant Ana. 41(5-8): 908-916. 
Karim, Z., S. M. Rahman, M. Idris, and A. J. M. S. Karim. 1988. Soil bulk density. A manual for determination of soil physical parameters. Soils and Irrigation Division, BARC.

Mazid, M. M., A. M. A. Faiz, T. H. Khan, and M. K. Alam. 1990. Effect of soil bulk density, moisture regime on the root development of wheat. Bangladesh J. Soil Sci. 12(1): 30-35.

Page, A. L., R. H. Miller and D. R. Kuny. 1982. Methods of Soil Analysis. Part 2. $2^{\text {nd }}$ edn., American Soc. Agron., Inc., Soil Sci. Soc. American Inc. Madison, Wisconsin, USA. Pp. 403-430.

Rahman, S. M. and A. Islam. 1998. Water transmission properties of two Bangladesh soils as affected by tillage depths. Soil water flux and hydraulic conductivity. AMA. Res. 10(3): 307-312.

Rahman, M. N., M. M. Rahman, M. B. Islam, R. A. Begum and A. T. M. A. I. Mondol. 2007. Effect of tillage practices on soil properties and moisture conservation under Maize -GM-T. Aman cropping sequence. Annual Research Report-2007. Soil Science Division. Bangladesh Agricultural Research Institute, Gazipur.

Ranamukhaarachchi, S. L., Rahman, M. M. and Begum, S. N. 2005. Soil fertility and land productivity under different cropping systems in highlands and medium highlands of Chandina sub district, Bangladesh. Asia Pacific J. Rural Dev. XV(1): 63-76.

Ranjan, B., R. D. Singh, S. Chandra, S. Kundu and H. S. Gupta. 2006. Effect of tillage and irrigation on yield and soil properties under rice, wheat system on a sandy clay loam soil of Uttaranchal. Indian. J. Agric. Sci. 76(7): 405-409.

Reddy, K. R., Khaleel, R. and Owerchash, M. R. 2004. Charges in soil physical properties due to organic waste application. A Review J. Environ. Quality. Pp. 10-141.

Weiqiang, L., L. Xiaojing, Q. Hailong, S. Jialing, and D. Deyu. 2004. Two phase tillage: A quick method for crop production in saline soils. Agrifood Res. Report. No. 68: 66-72. 